\title{
Dampak Pandemik Covid-19 Terhadap Kunjungan Turis Asing dan Domestik serta Tingkat Hunian Kamar Hotel Bintang di Indonesia
}

\author{
Soehardi ${ }^{1,}{ }^{*}$, Lina Purnamaasih ${ }^{2}$, Diana Rapitasari ${ }^{3}$ \\ ${ }^{1}$ Fakultas Ekonomi dan Bisnis, Universitas Bhayangkara Jakarta Raya; Jl. Raya Perjuangan, \\ Marga Mulya, Bekasi Utara, Jawa Barat 17121. Telp: 021-88955882, 889955883, e-mail:; e- \\ mail: soehardi@dsn.ubharajaya.ac.id \\ 2 Sekolah Pascasarjana, Universitas Pakuan; Jl. Pakuan 452 Tegallega Kecamatan Bogor \\ Tengah, Bogor; telp.0251-8312206, 8380137; e-mail: lina.purnama2020@yahoo.com \\ ${ }^{3}$ Fakultas Ekonomi, Universitas Bhayangkara Surabaya; Jl. A. Yani 114 Surabaya, Jawa Timur \\ 60231; telp.031-8285602, 8291056; e-mail: diana@ubhara.ac.id \\ * Korespondensi: e-mail: soehardi@dsn.ubharajaya.ac.id
}

\begin{abstract}
There is the influence of the Covid-19 pandemic on foreign and domestic tourist visits in Indonesia. The longer the Covid 19 pandemic, the more foreign and domestic tourists are postponing their visit to Indonesia due to the increasing number of Indonesians infected with Covid 19, the quality of personal protective equipment is not yet according to World Health Organization standards, incomplete hospital facilities in several cities in Indonesia, the limited number of doctors who treat the covid 19 pandemic and the anti-covid-19 vaccine has not been found. The decline in foreign and domestic tourism was also due to the temporary prohibition of foreign tourists from entering Indonesia and restrictions on domestic tourists from traveling to several cities and provinces in Indonesia, restrictions on the modes of air and sea transportation. There is the influence of the Covid-19 pandemic pandemic on hotel occupancy rates in Indonesia. The longer the Covid 19 pandemic, the lower the occupancy rate of star hotels in Indonesia is due to restrictions on activities in public places or facilities, restrictions on transportation modes, hotel room prices, hotel service quality and hotel facilities.
\end{abstract}

Keywords: Covid-19 Pandemic, Foreign and Domestic Tourists Visits, Hotel Room Occupancy Rates.

\begin{abstract}
Abstrak
Terdapat pengaruh pandemik covid-19 terhadap kunjungan turis asing dan domestik di Indonesia. Semakin lama pandemic covid 19, maka semakin banyak turis asing dan domestik yang menunda kunjungannya ke Indonesia disebabkan karena semakin meningkatnya penduduk Indonesia yang terinfeksi covid 19, kualitas alat pelindung diri belum sesuai standar World Health Organization, belum lengkapnya fasilitas rumah sakit di beberapa kota di Indonesia, keterbatasan jumlah dokter yang menangani pandemic covid 19 dan vaksin anti covid-19 belum diketemukan. Penurunan turus asing dan domestik juga disebabkan karena pelarangan sementara turis asing masuk ke Indonesia dan pembatasan turis domestik berpergi ke beberapa kota dan provinsi di Indonesia, pembatasan moda transportasi udara dan laut. Terdapat pengaruh pandemik pandemik covid-19 terhadap tingkat hunian hotel di Indonesia. Semakin lama pandemik covid 19 berlangsung, maka semakin menurun tingkat hunian hotel bintang di Indonesia disebabkan karena pembatasan kegiatan di tempat atau fasilitas umum, pembatasan moda transportasi, harga kamar hotel, kualitas pelayanan hotel dan fasilitas hotel.
\end{abstract}


Kata kunci: Pandemik Covid-19, Kunjungan Turis Asing dan Domestik, Tingkat Hunian Kamar Hotel.

\section{Pendahuluan}

Banyak turis asing dari beberapa negara termasuk Indonesia berkunjung ke tempattempat wisata di Wuhan, Provinsi Hubei, China pada tahun 2019 dan begitu pula banyak turis domestik berasal dari dari berbagai provinsi berkunjung ke tempat-tempat wisata di Wuhan, China. Wuhan Tianhe International Airport merupakan pintu masuk dan keluar turis asing dari berbagai dunia, termasuk turis asing dari Indonesia. Turis Indonesia yang berkunjung ke China dengan menggunaan izin penerbangan charter yang dimiliki oleh Batik Air dan Sriwijaya Air dengan rute penerbangan pulang pergi dari Wuhan Tianhe International Airport ke Ngurah Rai International Airport, Bali dan Sam Ratulangi International Airpor, Manado.

Turis asing yang berkunjung ke China dan turis asal China inilah yang membawa penyakit covid-19 menjadi semakin bertambah orang-orang yang terinfeksi, meninggal dunia dan sembuh di beberapa Negara, termasuk Indonesia. Perbandingan penduduk Indonesia yang sembuh dan meinggal karena covid pada bulan Juni 2020 adalah 2.500:18.735 atau 1:13,34. Rata-rata persentase penduduk Indonesia yang terinfeksi karena covid 19 selama 4 bulan terhitung bulan Maret, April, Mei dan Juni 2020 mengalami peningkatan sebesar 242,33\%. Rata-rata persentase penduduk Indonesia yang telah meninggal dunia karena covid 19 selama 4 bulan terhitung bulan Maret, April, Mei dan Juni 2020 mengalami peningkatan sebesar $179,33 \%$. Rata-rata persentase penduduk Indonesia yang sembuh karena covid 19 selama 4 bulan terhitung bulan Maret, April, Mei dan Juni 2020 mengalami peningkatan sebesar $2.381,67 \%$.

Tabel 1. Data Pandemik Covid-19 di Indonesia

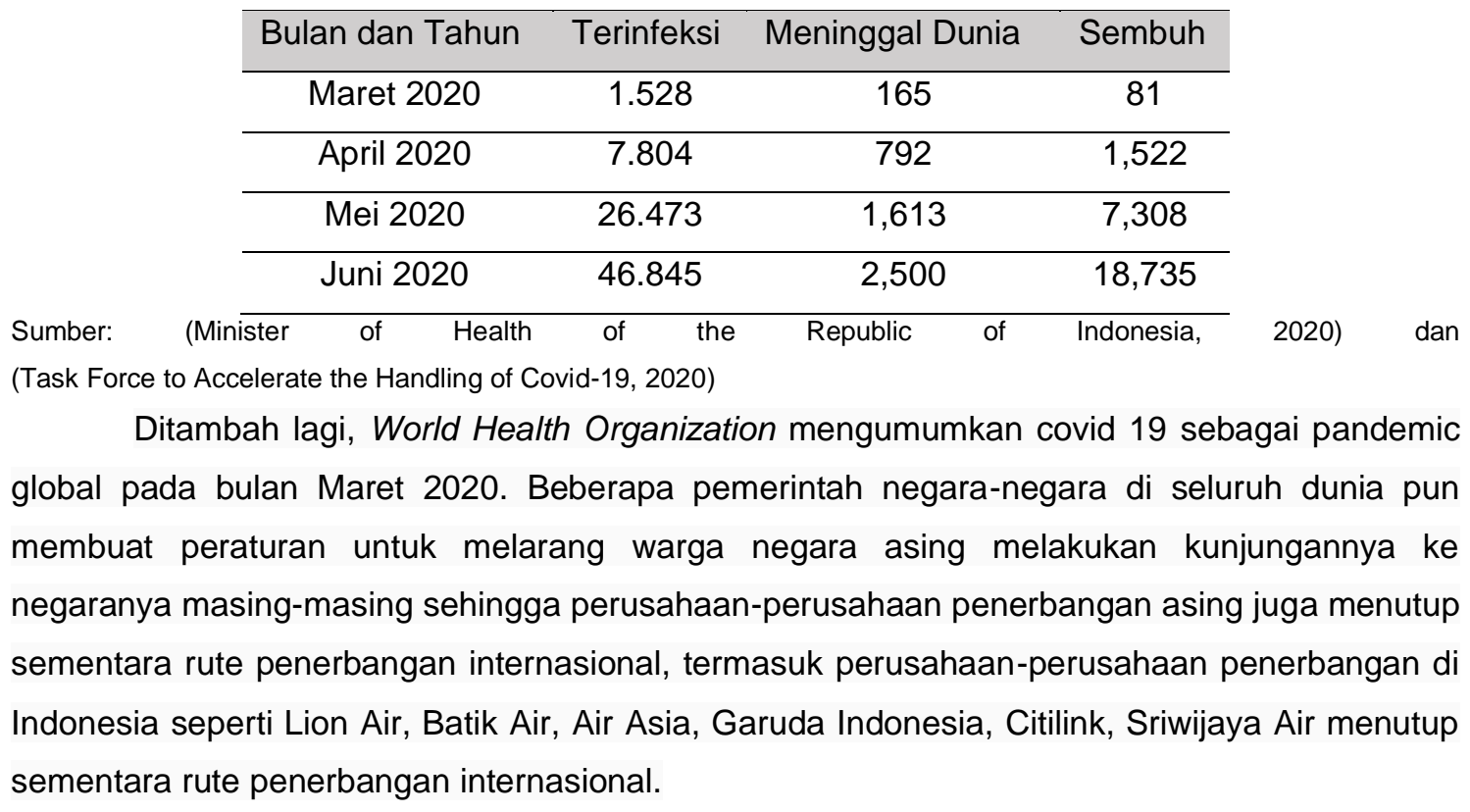


Pelarangan turis asing berkunjung ke Indonesia dan penutupan sementara rute penerbangan internasional oleh pemerintah Indonesia menyebabkan turis asing menunda kunjungannya ke Indonesia selama masa pandemic covid 19pada bulan Maret hingga Juni 2020. Pemberlakukan Pembatasan Sosial Berskala Besar yang dilakukan oleh pemerintah Indonesia juga membatasi jumlah penumpang pesawat terbang juga menyebabkan turis domestic menunda kembali rencana kunjungan sosial budaya, bisnis dan rekreasi ke beberapa kota dan provinsi selama masa pandemic covid 19 bulan Maret hingga Juni 2020 sehingga berdampak pada penurunan tingkat hunian hotel di beberapa provinsi di Indonesia. Penurunan tingkat hunian hotel akan berdampak pada penurunan pendapatan pajak perhotelan dan

Penyebaran covid 19 semakin meningkat dan transmisi lokal, maka semakin meningkatnya jumlah kasus terinfeksi, meninggal dunia dan sembuh di Indonesia, sehingga pemerintah provinsi, kotamdaya dan kabupaten membuat peraturan tentang Pembatasan Sosial Berskala Besar bidang perhotelan antara lain: peliburan tempat kerja, pemabtasan kegiatan sosial dan budaya, pembatasan kegiatan di tempat atau fasilitas umum dan pembatasan moda transportasi darat, laut dan udara. Berdasarkan beberapa identifikasi permasalahan tersebut diatas, maka tujuan penelitian ini adalah untuk mengetahui pengaruh pandemic covid 19 terhadap kunjungan turis asing dan domestic dan pengaruh pandemic covid 19 terhadap tingkat hunian hotel di Indonesia.

Covid-19 menurut (WHO, 2020) adalah penyakit menular yang disebabkan oleh jenis coronavirus yang baru ditemukan. Virus baru dan penyakit yang disebabkannya ini tidak dikenal sebelum mulainya wabah di Wuhan, Tiongkok, bulan Desember 2019. Gejala-gejala COVID-19 yang paling umum adalah demam, batuk kering, dan rasa lelah. WHO juga mengumumkan Covid-19 sebagai pandemic global tanggal 11 Maret 2020,. COVID-19 ini sekarang menjadi sebuah pandemi yang terjadi di banyak negara di seluruh dunia. Setelah pengumuman ini, beberapa negara melarang orang asing untuk berkunjung ke negaranya, termasuk pemerintah Indonesia melarang warga negara asing berkunjung ke Indonesia. Pelarangan warga negara asing ini berdampak pada terhentinya rute penerbangan internasional dan berpengaruh pada penurunan wisatawan asing berkunjung ke Jakarta, Indonesia.

Pemerintah Indonesia melalui Kementerian Perhubungan juga menutup sementara rute penerbangan internasional dari dan menuju China mulai 5 Februrai 2020 sampai dengan batas waktu yang akan ditentukan kemudia. Beberapa perusahaan penerbangan yang melayani rute menuju China terdiri dari: Garuda Indonesia, Citilink, Batik Air, Lion Air, dan Sriwijaya Air. Pemerintah China juga sebelumnya telah menutup sementara rute penerbangan dari dan menuju Wuhan Tianhe International Airport pada tanggal 20 Januari hingga 8 April 2020 (Ramli \& Djumena, 2020). 
Submitted: 11 Agustus 2020; Revised: 26 Agustus 2020; Accepted: 22 September 2020; Published: 30 September 2020

Hotel bintang ialah usaha yang menggunakan bangunan atau sebagian bangunan yang disediakan secara khusus dan setiap orang dapat menginap makan serta memperoleh pelayanan dan fasilitas lainnya dengan pembayaran dan telah memenuhi persyaratan sebagai hotel berbintang seperti yang telah diterbitkan oleh Direktorat Jenderal Pariwisata atau Dinas Pariwisata, Ciri khusus dari hotel berbintang adalah mempunyai restoran yang berada di bawah manajemen hotel tersebut,

Tingkat hunian hotel dikur dari pemanfaatan kapasitas fisik hotel dengan dua cara, yaitu: using overnights or roomnights as a basis, Occupancy overnight adalah jumlah tamu yang menginap dibagi dengan jumlah tempat tidur yang tersedia untuk dijual dikalikan 100, Occupancy roomnights adalah jumlah kamar dibagi dengan jumlah kamar tersedia untuk dijual dikalikan 100 (Stanislav Ivanov, 2014).

Tarif hunian dianggap sangat penting bagi manajemen hotel secara umum, dan untuk departemen penjualan pada khususnya, Adanya tingkat hunian yang kurang dari kapasitas hotel berarti bahwa ada peluang penjualan yang hilang, yang mengarah pada penurunan pendapatan hotel, Oleh karena itu, banyak hotel dengan tingkat hunian rendah lebih memilih untuk terus berfungsi secara normal di masa non-puncak, selama tingkat hunian saat ini mencakup biaya variabel dan berkontribusi dalam menutupi biaya tetap (upah, gaji, depresiasi aset, sewa, listrik, dan biaya lainnya), Di sisi lain, jika permintaan untuk layanan hotel melebihi kapasitas hotel, ini berarti bahwa tingkat hunian hotel mencapai tingkat maksimum, karena manajemen hotel (Saleem \& Al-Juboori, 2013).

\section{Metode Penelitian}

Populasi adalah seluruh karyawan hotel berbintang di seluruh Indonesia. Sampel yang digunakan adalah purposive sampling berasal dari karyawan yang bekerja di hotel berbintang di Provinsi DKI Jakarta, Jawa Barat, Jawa Tengah, Jawa Timur, Bali dan Sulawesi Utara berjumlah 71. Metode penelitian yang digunakan adalah metode penelitian kuantitatif dengan analisis construct reliability and validity, cronbach's alpha, average variance axtracted (AVE), uji $t$ dan $P$ values serta koefisien determinasi dengan menggunakan software Partial Least Square (PLS).

\section{Hasil dan Pembahasan}

Jumlah responden tercatat 71 orang terdiri dari 26 wanita dan 45 laki-laki. Pendidikan responden lulusan SMA dan SMK berjumlah 48 orang, Diploma dan sarjana berjumlah 19 orang dan Masteral berjumlah 4 orang serta tidak ada yang bergelar Doktoral. Tempat bekerja responden di Provinsi DKI Jakarta berjumlah 17 orang, Provinsi Jawa Barat berjumlah 12 orang, Provinsi Jawa Tengah berjumlah 10 orang, Provinsi Jawa Timur berjumlah 11 orang, Provinsi Bali berjumlah 8 orang dan Provinsi Sulawesi Utara berjumlah 13 orang.

Berdasarkan tabel 2 menunjukkan bahwa penduduk Provinsi DKI Jakarta yang terinfeksi dan meninggal dunia karena covid 19 menduduki tempat pertama pada bulan Maret 
hingga Mei 2020, diikuti Provinsi Jawa Timur, Jawa Barat, Jawa Tengah, Sulawesi Selatan, Bali, Sumatera Utara dan Kalimantan Tengah. Perkembangan selanjutnya tercatat bahwa penduduk Provinsi Jawa Timur yang terinfeksi dan meninggal dunia karena covid 19 menduduki tempat pertama pada bulan Juni 2020, diikuti Provinsi DKI Jakarta, Jawa Barat, Jawa Tengah, Sulawesi Selatan, Bali, Sumatera Utara dan Kalimantan Tengah.

Berdasarkan tabel 2 terdata bahwa penduduk Indonesia yang sembuh apabila dibandingkan dengan meninggal dunia pada bulan Maret 2020 adalah 1:2,04. Namun sebaliknya penduduk Indonesia yang meninggal dunia apabila dibandingkan dengan sembuh pada bulan Juni 2020 adalah 1:13,34. Hal ini membuktikan adanya peningkatan tentang kesadaran penduduk Indonesia untuk mematuhi protokol kesehatan baik ketika berada di dalam rumah, lingkungan masyarakat, tempat kerja dan tempat-tempat fasilitas umumnya lainnya.

Tabel 2. Data Pandemik Covid-19 di Indonesia Tahun 2020

\begin{tabular}{|c|c|c|c|c|}
\hline \multirow[t]{2}{*}{ Bulan } & \multirow[b]{2}{*}{ Lokasi } & \multicolumn{3}{|c|}{ Meninggal } \\
\hline & & Terinfeksi & Dunia & Sembuh \\
\hline \multirow[t]{8}{*}{ Maret 2020} & Indonesia & 1.528 & 165 & 81 \\
\hline & Jakarta & 747 & 83 & 48 \\
\hline & Jawa Timur & 93 & 8 & 17 \\
\hline & Jawa Barat & 119 & 19 & 9 \\
\hline & Jawa Tengah & 46 & 7 & 2 \\
\hline & Bali & 19 & 2 & 0 \\
\hline & Sumatera Utara & 20 & 2 & 11 \\
\hline & Sulawesi Selatan & 33 & 4 & 1 \\
\hline \multirow[t]{8}{*}{ April 2020} & Indonesia & 7.804 & 792 & 1,522 \\
\hline & Jakarta & 4.175 & 371 & 486 \\
\hline & Jawa Timur & 951 & 88 & 165 \\
\hline & Jawa Barat & 862 & 77 & 90 \\
\hline & Jawa Tengah & 449 & 44 & 51 \\
\hline & Bali & 186 & 4 & 75 \\
\hline & Sumatera Utara & 114 & 12 & 41 \\
\hline & Sulawesi Selatan & 453 & 37 & 115 \\
\hline \multirow[t]{9}{*}{ Mei 2020} & Indonesia & 26.473 & 1,613 & 7,308 \\
\hline & Jakarta & 7.383 & 521 & 2,245 \\
\hline & Jawa Timur & 4.848 & 396 & 654 \\
\hline & Jawa Barat & 2.157 & 142 & 542 \\
\hline & Jawa Tengah & 1.350 & 90 & 579 \\
\hline & Bali & 363 & 4 & 267 \\
\hline & Sumatera Utara & 273 & 31 & 87 \\
\hline & Sulawesi Selatan & 1.510 & 72 & 564 \\
\hline & Kalimantan Tengah & 398 & 19 & 164 \\
\hline \multirow[t]{4}{*}{ Juni, 2020} & Indonesia & 46.845 & 2,500 & 18,735 \\
\hline & Jakarta & 9.525 & 599 & 4,682 \\
\hline & Jawa Timur & 12.695 & 813 & 4.391 \\
\hline & Jawa Barat & 3.091 & 175 & 1.520 \\
\hline
\end{tabular}




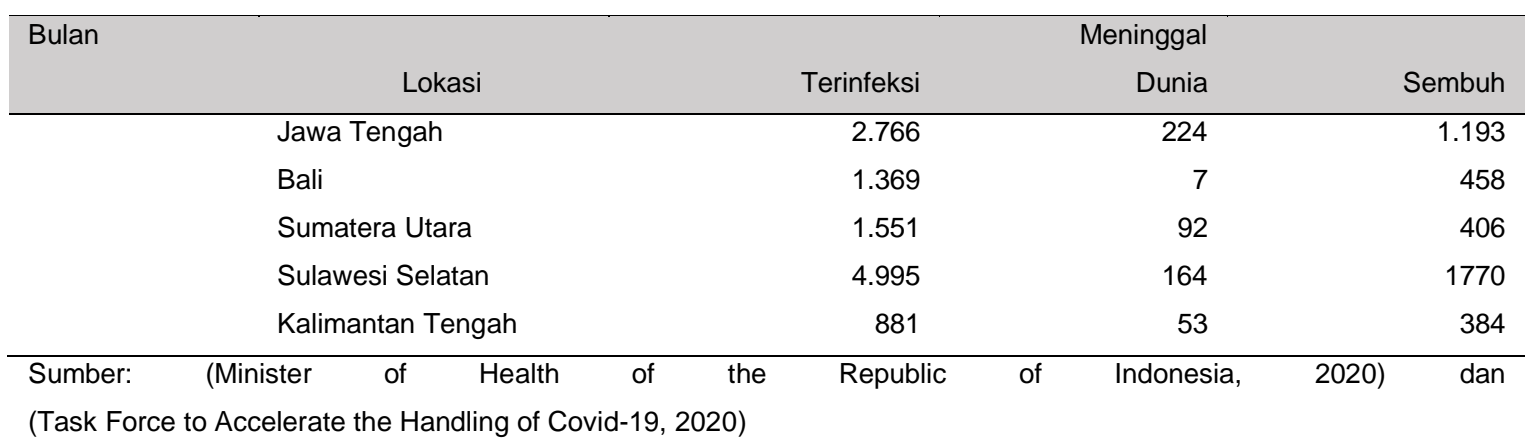

Tabel 3 terdata bahwa turis asing yang berkunjung ke Indonesia pada bulan Januari hingga Juni 2020 berjumlah 3.089 .659 orang atau mengalami penurunan sebesar 59,96\% dibandingkan pada bulan Januari hingga Juni 2020 berjumlah 7.715 .512 orang. Turis asing yang berkunjung ke Indonesia pada bulan Januari hingga Juni 2019 berjumlah 7.715 .512 orang atau mengalami kenaikan sebesar 2,89\% dibandingkan pada bulan Januari hingga Juni 2018 berjumlah 7.498 .378 orang. Begitu pula berdasarkan table 3 , turis domestik pada bulan Januari hingga Juni 2020 berjumlah 85.000 .000 orang atau mengalami penurunan sebesar $69,09 \%$ dibandingkan pada bulan Januari hingga Juni 2020 berjumlah 275.000 .000 orang. Turis domestik pada bulan Januari hingga Juni 2019 berjumlah 275.000 .000 orang atau mengalami penurunan sebesar 9,36\% dibandingkan pada bulan Januari hingga Juni 2020 berjumlah $303,403.888$ orang

Tabel 3. Kunjungan Turis Asing dan Domestik di Indonesia

\begin{tabular}{|c|c|c|c|}
\hline \multirow[t]{2}{*}{ Turis } & 2018 & 2019 & 2020 \\
\hline & (Januari - Juni) & (Januari - Juni) & (Januari - Juni) \\
\hline Asing & $7,498,378$ & $7,715,512$ & $3,089,659$ \\
\hline Domestik & $303,403,88$ & $275,000,000$ & $85,000,000$ \\
\hline
\end{tabular}

Sumber: (Ministry of Tourism and Economy Creative of the Republic of Indonesia, 2020)

Berdasarkan tabel 4 menunjukkan bahwa rata-rata turis asing yang berkunjung ke Indonesia pada bulan Januari hingga Juni 2020 mengalami penurunan sebesar 59,96\% apabila dibandingkan pada bulan Januari hingga Juni 2019. Turis asing yang berkunjung ke Indonesia pada bulan Januari hingga Juni berasal dari negara Malaysia, Timor Leste, Singapore, Australia, Chinese, India, Japanese, United States of America, South Korea and United Kingdom, Rusia, Germany, Philippines, France, Dutch, Taiwan, Saudi Arabiah, Canada, New Zealand, Thailand, Vietnam and others countries. 
Dampak Pandemik Covid-19 Terhadap Kunjungan Turis Asing dan Domestik serta Tingkat Hunian Kamar Hotel Bintang di Indonesia

Tabel 4. Turis Asing Berdasarkan Negara Tahun 2019 dan 2020

\begin{tabular}{|c|c|c|c|}
\hline Turis Asing Berdasarkan & 2019 & 2020 & Persentase \\
\hline Negara & Januari - Juni & Januari - Juni & \\
\hline Malaysia & $1,533,700$ & 675,420 & -55.96 \\
\hline Timor Leste & 592,900 & 524,660 & -11.51 \\
\hline Singapore & 919,900 & 267,610 & -70.91 \\
\hline Australia & 608,300 & 249,300 & $-59,02$ \\
\hline Chinese & $1,050,000$ & 202,200 & -80.74 \\
\hline India & 336,200 & 106,500 & -68.32 \\
\hline Japanese & 235,000 & 88,700 & -62.26 \\
\hline United States of America & 217,000 & 75,700 & -65.12 \\
\hline South Korea & 175,900 & 69,900 & -60.26 \\
\hline United Kingdom & 178,800 & 65,800 & -36.80 \\
\hline Rusia & 79,700 & 60,000 & -24.72 \\
\hline Germany & 116,800 & 42,500 & -36.39 \\
\hline Philippines & 134,500 & 41,500 & -69.14 \\
\hline France & 109,000 & 41,100 & -62.29 \\
\hline Dutch & 84,100 & 38,700 & -53.98 \\
\hline Taiwan & 101,100 & 33,900 & -66.47 \\
\hline Saudi Arabiah & 63,800 & 29,700 & -53.45 \\
\hline Canada & 52,500 & 22,100 & -57.90 \\
\hline New Zealand & 57,600 & 19,200 & -66.67 \\
\hline Thailand & 62,600 & 18,700 & -70.13 \\
\hline \multirow[t]{7}{*}{ Vietnam } & 41,100 & 18,200 & -55.72 \\
\hline & & Total & $-118,776$ \\
\hline & & Countries & 21 \\
\hline & & Rata-Rata & -56.56 \\
\hline & & Other & -3.40 \\
\hline & & Countries & \\
\hline & & Total & $-59,96$ \\
\hline
\end{tabular}

Sumber: (Biro Pusat Statistik, 2020a)

Tabel 5 terdata bahwa turis domestic ditinjau dari tempat tinggal provinsi tahun 2018 terbanyak berasal dari Provinsi Jawa Timur sebesar $17,55 \%$ atau $53,247,382.34$ orang dari $303,403,888$ orang.

Tabel 5. Turis Domestik Berdasarkan Provinsi in 2018

\begin{tabular}{cr}
\hline Domestic Tourists Based on Provinces Residences & Persentase \\
\hline East Java Province & 17.55 \\
\hline West Jave Province & 17.54 \\
\hline Central Java Province & 14.21 \\
\hline Capital Special Region of Jakarta Province & 8.23 \\
\hline Banten Province & 4.38 \\
\hline North Sumatera Province & 3.41 \\
\hline South Sulawesi Province & 3.17 \\
\hline Special Region of Yogyakarta Province & 2.59 \\
\hline
\end{tabular}

Copyright @ 2020 Jurnal JKI 20 (3): 291 - 308 (September 2020) 


\begin{tabular}{cr}
\hline Domestic Tourists Based on Provinces Residences & Persentase \\
\hline Lampung Province & 2.27 \\
\hline Bali Province & 2.18
\end{tabular}

Sumber: (Biro Pusat Statistik, 2018a)

Data tabel 6 bahwa rata-rata tingkat penghunian kamar hotel berbintang pada bulan Januari hingga Juli tahun 2020 sebesar 29,36\% atau mengalami penurunan sebesar 43,42\% apabila dibandingkan pada bulan Januari hingga Juli tahun 2019 sebesar 51,89\%

Tabel 6. Tingkat Penghunian Kamar Hotel Bintang di Indonesia Tahun 2019 dan 2020

\begin{tabular}{cll}
\hline Bulan & 2019 & 2020 \\
\hline Januari & 51,47 & 49,17 \\
\hline Februari & 52,44 & 49,22 \\
\hline Maret & 52,89 & 32,24 \\
\hline April & 53,90 & 12,67 \\
\hline Mei & 43,53 & 14,45 \\
\hline Juni & 52.27 & 19.70 \\
\hline Juli & 56.73 & 28,07 \\
\hline Rata-Rata TPH & 51,89 & 29,36
\end{tabular}

Sumber: (Kementerian Pariwsiata dan Ekonomi Kreatif Republik Indonesia, 2020)

Data tabel 7 membuktikan bahwa tingkat hunian hotel bintang di 34 Provinsi di Indonesia pada bulan Januari hingga Juli 2020 sebesar 32,41\% atau mengalami penurunan sebesar $60,10 \%$ apabila dibandingkan tingkat hunian hotel bintang di 34 Provinsi di Indonesia pada bulan Januari hingga Juli 2019 sebesar 51,89 . Tercatat bahwa tingkat hunian kamar hotel tertinggi pada bulan Januari hingga Juli 2020 berasal dari Provinsi Kalimantan Selatan diikuti DKI Jakarta, Bengkulu, Lampung, Sulawesi Utara dan Sulawesi Selatan. Sedangkan tingkat hunian kamar hotel terendah pada bulan Januari hingga Juli 2020 berasal dari Provinsi Kepulauan Bangka Belitung, Gorontalo, Nusa Tenggara Barat, Sulawesi Barat dan Maluku Utara.

Tabel 7. Tingkat Hunian Kamar Hotel Bintang di 34 Provinsi di Indonesia

\begin{tabular}{ccc}
\hline Provinsi & Januari - Juli 2020 & Januari - Juli 2019 \\
\hline Aceh & 27.30 & 39.77 \\
\hline Sumatera Utara & 29.75 & 47.26 \\
\hline Sumatera Barat & 30.24 & 51.55 \\
\hline Riau & 29.61 & 45.25 \\
\hline Jambi & 30.89 & 41.14 \\
\hline Sumatera Selatan & 37.51 & 51.85 \\
\hline Bengkulu & 38.04 & 58.83 \\
\hline Lampung & 37.59 & 54.57 \\
\hline Kepulauan Bangka Belitung & 23.13 & 32.04 \\
\hline Kepulauan Riau & 27.13 & 49.47 \\
\hline DKI Jakarta & 40.97 & 60.33 \\
\hline Jawa Barat & 32.93 & 49.79
\end{tabular}


Dampak Pandemik Covid-19 Terhadap Kunjungan Turis Asing dan Domestik serta Tingkat Hunian Kamar Hotel Bintang di Indonesia

\begin{tabular}{|c|c|c|}
\hline Provinsi & Januari - Juli 2020 & Januari - Juli 2019 \\
\hline Jawa Tengah & 26.50 & 44.16 \\
\hline D. I. Yogyakarta & 33.34 & 55.83 \\
\hline Jawa Timur & 33.54 & 52.78 \\
\hline Banten & 33.05 & 47.36 \\
\hline Nusa Tenggara Barat & 24.54 & 36.24 \\
\hline Nusa Tenggara Timur & 28.27 & 47.66 \\
\hline Kalimantan Barat & 30.32 & 45.12 \\
\hline Kalimantan Timur & 34.22 & 54.20 \\
\hline Sulawesi Utara & 37.24 & 63.49 \\
\hline Sulawesi Tengah & 32.03 & 40.74 \\
\hline Sulawesi Selatan & 36.45 & 45.59 \\
\hline Sulawesi Tenggara & 27.64 & 36.69 \\
\hline Gorontalo & 25.73 & 45.32 \\
\hline Sulawesi Barat & 26.62 & 45.87 \\
\hline Maluku & 28.89 & 30.72 \\
\hline
\end{tabular}

Sumber: (Kementerian Pariwsiata dan Ekonomi Kreatif Republik Indonesia, 2020)

\section{Construct Realiability and Validity}

Berdasarkan tabel 8 gambar 2, 3 dan 4 dengan menggunakan software Partial Least Square (PLS) bahwa uji validitas dan reliabilitas dapat digunakan dengan beberapa cara antara lain: composite reliability, cronbach's alpha and average variance extracted (AVE). Pada uji composite reliability tentang pandemik covid-19, turis asing dan domestik serta tingkat hunian kamar hotel diperoleh nilai $\geq 0,70$ berarti nilai reliabilitas komposit tentang pandemik covid-19, turis asing dan domestik serta tingkat hunian kamar hotel dapat dikatakan valid atau dapat diterima. Pada uji cronbach's alpha tentang turis asing dan domestik serta tingkat hunian kamar hotel diperoleh nilai $\geq 0,70$ berarti nilai cronbach's alpha tentang turis asing dan domestik serta tingkat hunian kamar hotel dapat dikatakan reliabel atau konsisten. Meskipun uji cronbach's alpha tentang pandemik covid-19 diperoleh nilai 0,668 dapat juga diartikan reliabel atau konsisten. Pada uji Average Variance Extracted (AVE) tentang pandemik covid-19, turis asing dan domestik serta tingkat hunian kamar hotel diperoleh nilai $\leq 0,40$ artinya rata-rata variance yang diekstrak oleh program tidak dapat diterima. Meskipun nilai AVE tidak dapat diterima dan nilai composite reliability serta cronbach's alpha dapat diterima, maka penelitian dapat dilanjutkan ke tahap selanjutnya.

Pada Tabel 8 menjelaskan tentang Construct Realiability and Validity. 
Tabel 8. Construct Realiability and Validity.

Construct Reliability and Validity

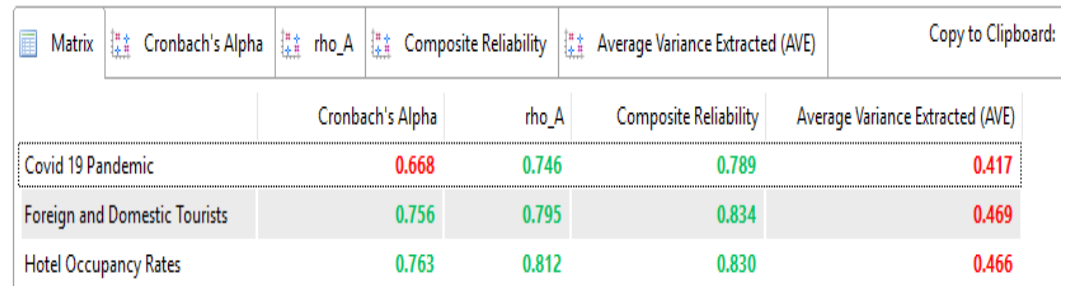

Sumber: Hasil Pengolahan Data (2020)

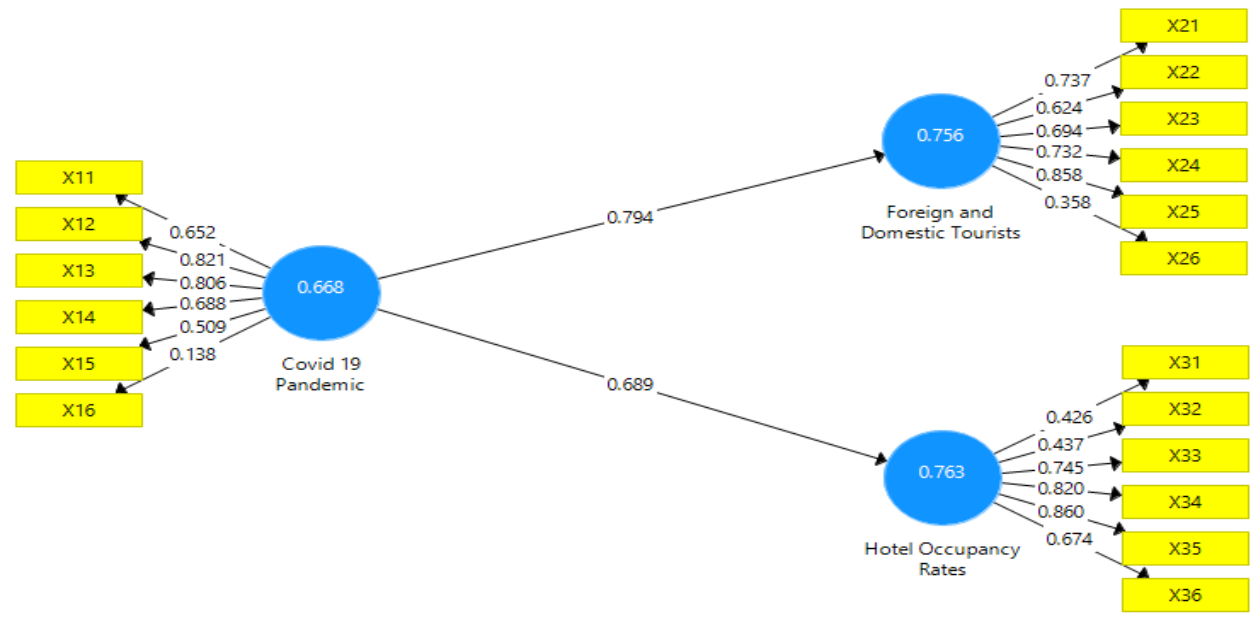

Gambar 1. Construct Realiability and Validity

Pada gambar 2, 3 dan 4 menjelaskan tentang Composite Reliability, Cronbach's Alpha dan Average Variance Extracted (AVE).

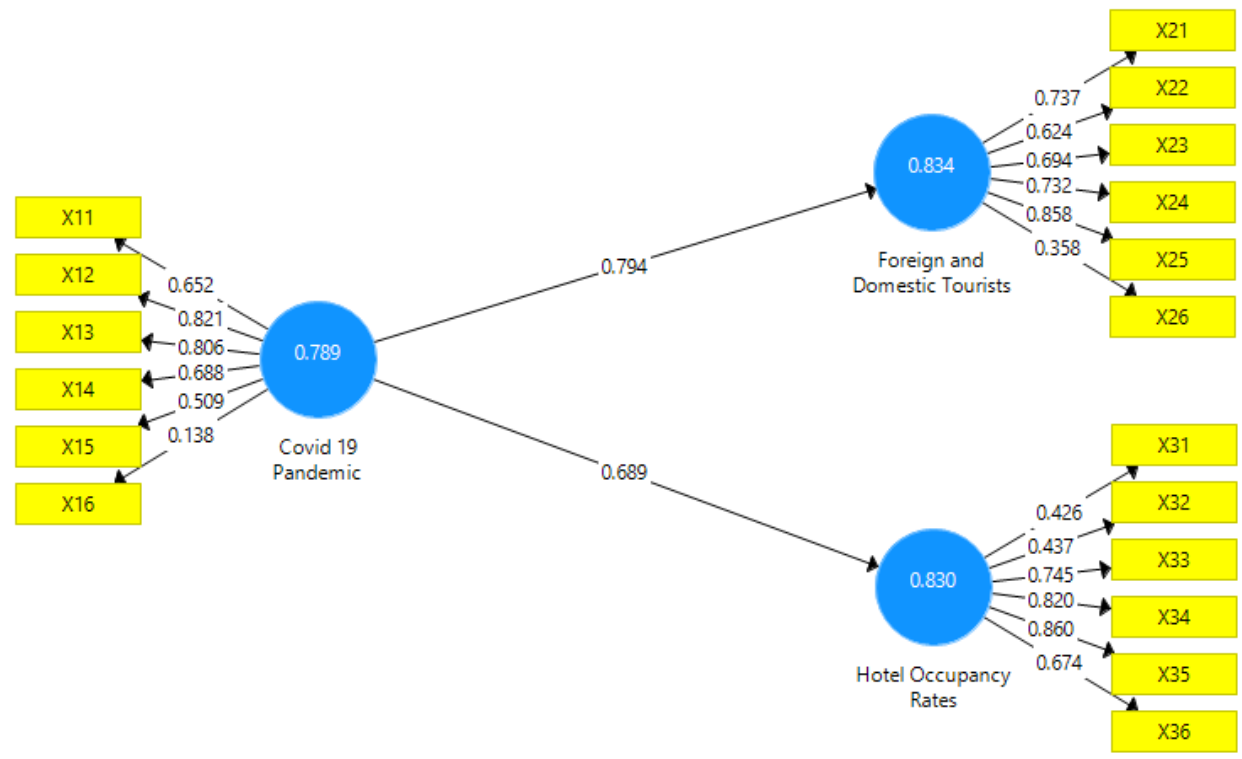

Gambar 2. Composite Reliability 


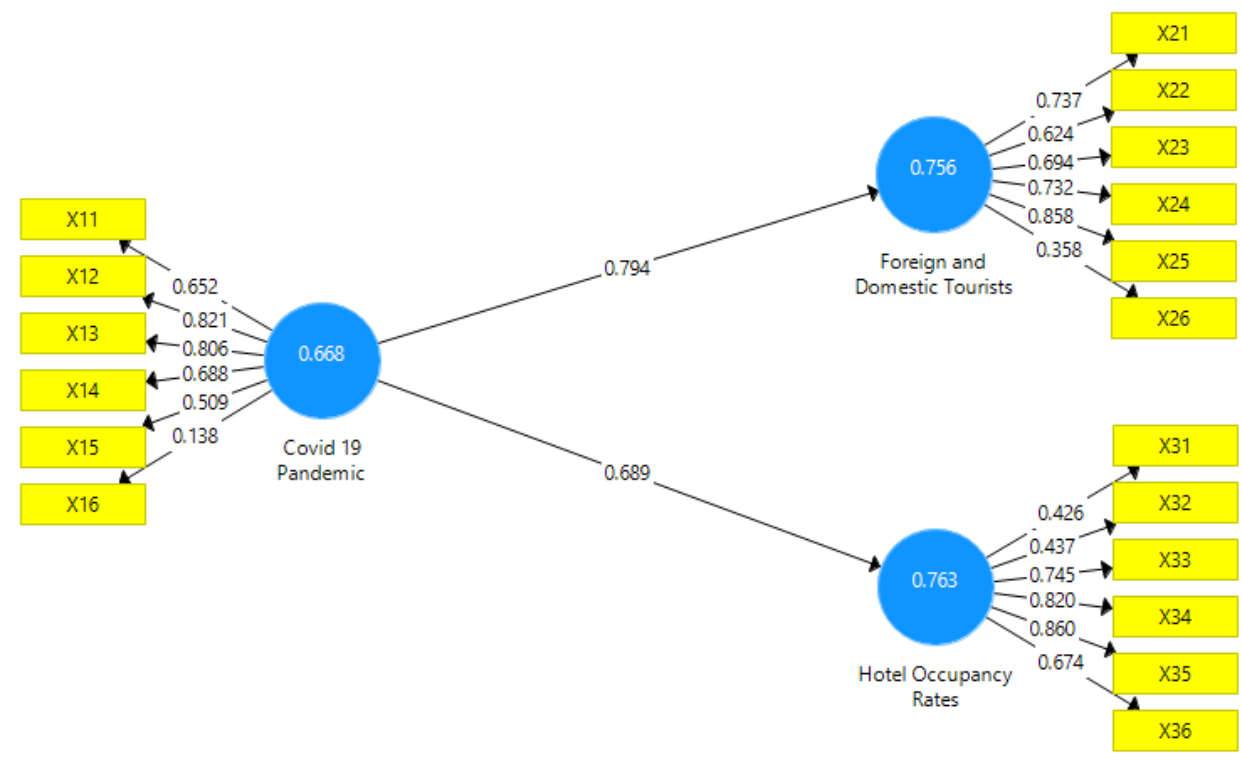

Gambar 3. Cronbach's Alpha

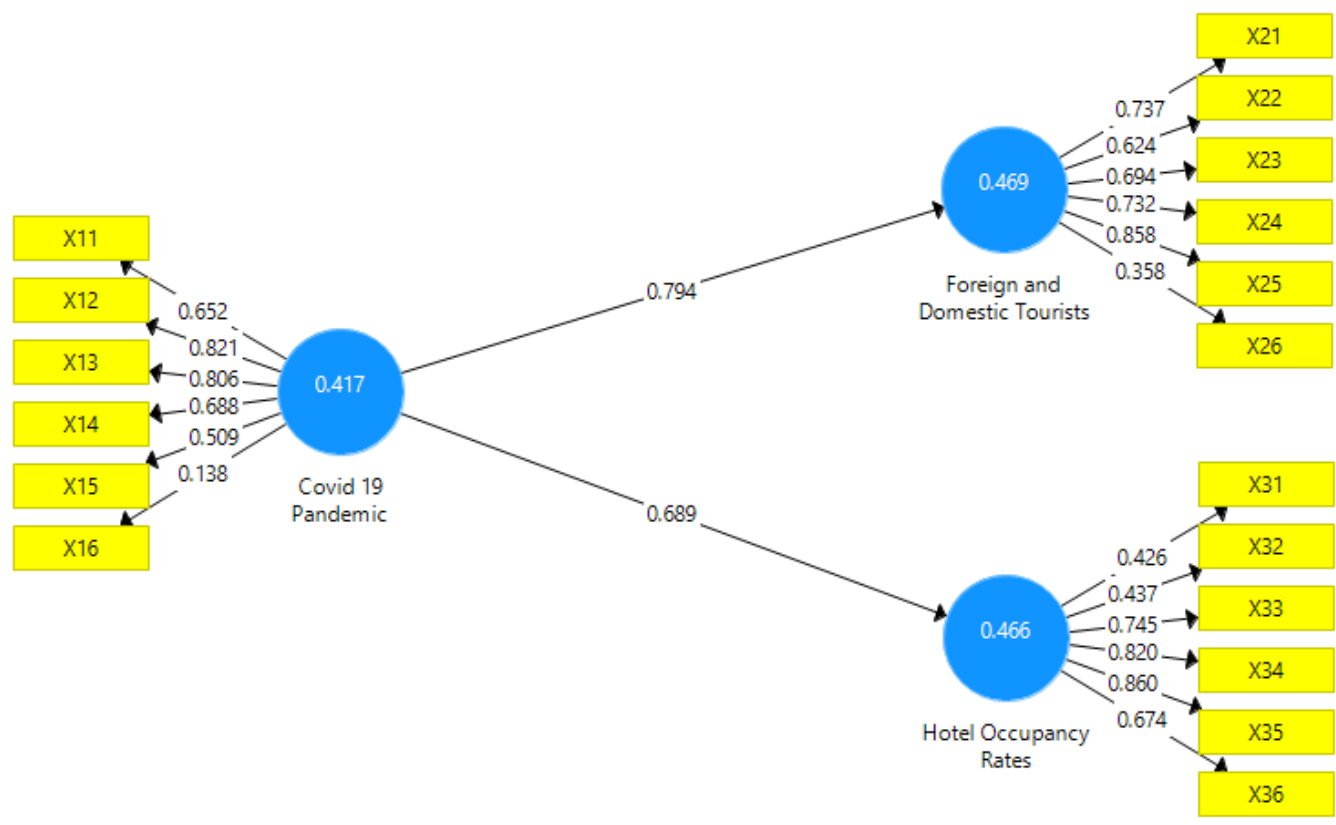

Gambar 4. Average Variance Extracted (AVE)

\section{Uji T dan P Values}

Berdasarkan tabel 9 gambar 5 dan 6 uji t dan P values menghasilkan hipotesis pertama bahwa $t$ hitung $(16,673) \geq t$ tabel $(1,988)$ dan nilai $P$ hitung $(0,000) \leq P$ tabel $(0,05)$, dapat diartikan ada pengaruh pandemik pandemik covid-19 terhadap kunjungan turis aing dan domestic di Indonesia. Hipotesis kedua bahwa t hitung $(9,738) \geq t$ tabel $(1,988)$ dan nilai $P$ hitung $(0,000) \leq P$ tabel $(0,05)$, dapat diartikan ada pengaruh pandemik pandemik covid-19 terhadap tingkat hunian hotel di Indonesia.

Pada tabel 9 menjelaskan tentang uji t dan $P$ values. 
Tabel 9. Uji t dan P value

Path Coefficients

\begin{tabular}{|c|c|c|c|c|c|c|c|c|}
\hline \multirow[t]{2}{*}{ Mean, STDEV, T-Values, P-Values } & \multicolumn{2}{|c|}{ Confidence Intervals } & \multicolumn{2}{|c|}{ Confidence Intervals } & Bias Corrected & Samples & \multicolumn{2}{|c|}{ Copy to Clipboard: } \\
\hline & & Original S & ampl... & Sample Mean (... & Standard Devia. & T Statistics & O/STDEV|) & P Values \\
\hline Covid 19 Pandemic $\rightarrow$ Foreign and Do & mestic & c Tourists & 0.794 & 0.806 & 0.04 & & 16.673 & 0.000 \\
\hline Covid 19 Pandemic $\rightarrow$ Hotel Occupan & cy Rat & & 0.689 & 0.724 & 0.07 & & 9.738 & 0.000 \\
\hline
\end{tabular}

Sumber: Hasil Pengolahan Data (2020)

Pada gambar 5 dan 6 menjelaskan tentang $t$ values dan $P$ values.

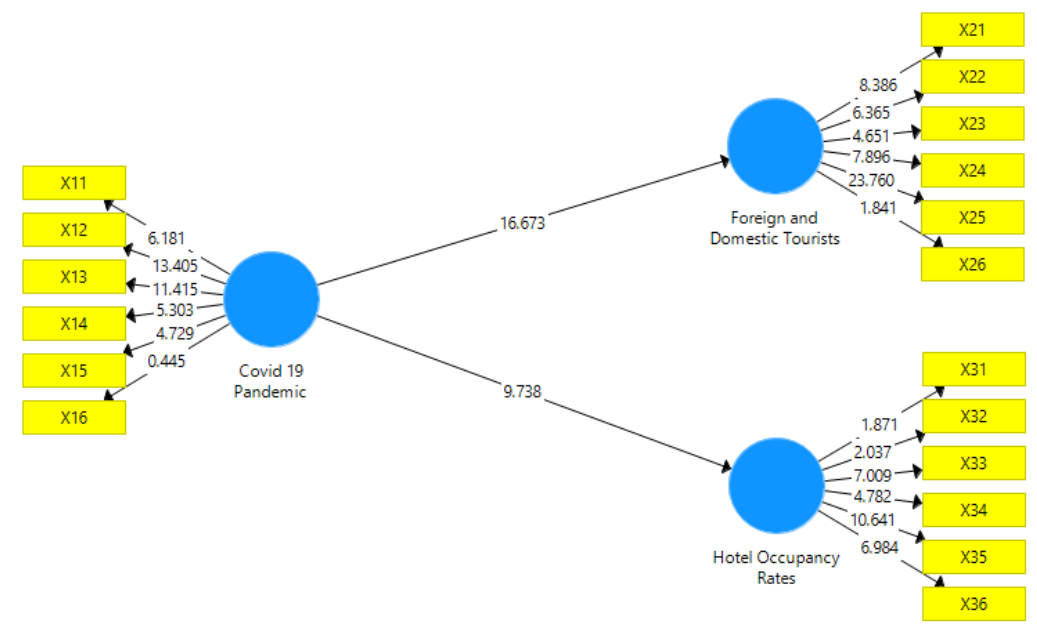

Gambar 5. T Values

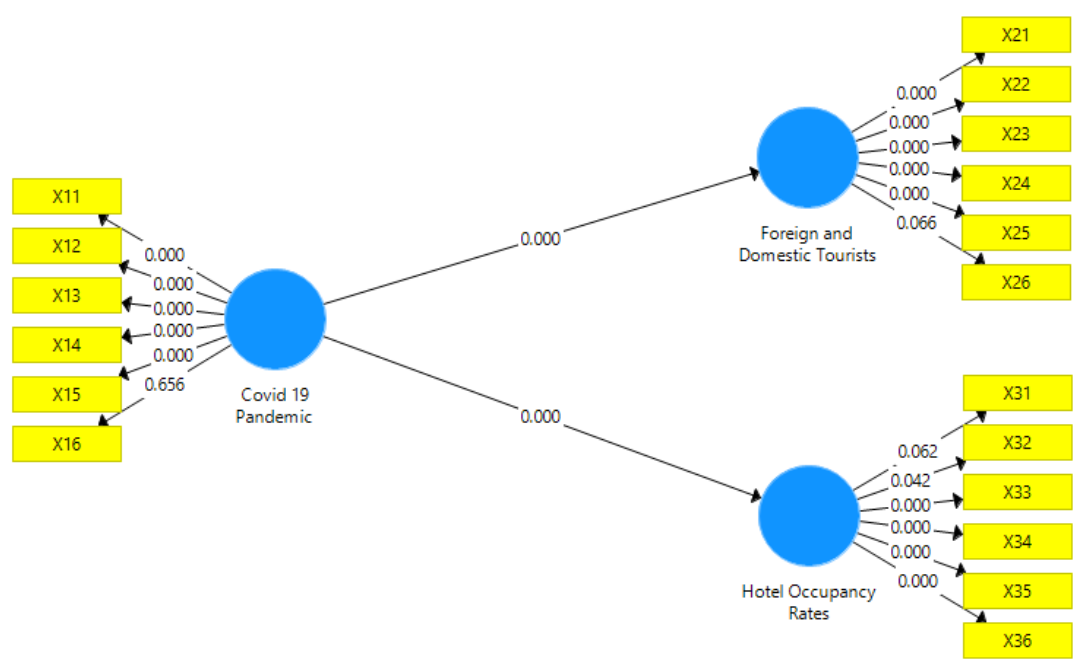

Gambar 6. P Values

\section{Koefisien Determinasi}

Berdasarkan tabel 10 dan Gambar 5 koefisen determinasi atau $R$ square dipeorleh nilai $\mathrm{R}$ square tentang turis asing dan domestik sebesar 0,630 , artinya variabel laten turis asing dan domestik berpengaruh $63,00 \%$ dan $37,00 \%$ dipengaruhi oleh variabel laten lainnya. Begitu pula dengan nilai $R$ square tentang tingkat hunian kamar hotel sebesar 0,475 , artinya variabel laten tingkat hunian kamar hotel berpengaruh $47,50 \%$ dan $52,50 \%$ dipengaruhi oleh variabel laten lainnya. Model struktural dengan $\mathrm{R}$ square semakin mendekati 1 berarti semakin baik. 
Pada tabel 10 menjelaskan tentang $\mathrm{R}$ square.

Tabel 10. R Square

\begin{tabular}{|c|c|c|c|c|}
\hline \multicolumn{5}{|l|}{ R Square } \\
\hline \multirow[t]{2}{*}{ 圊 Matrix } & 㩰去 R Square & 㩰萃 R Square Adjusted & \multirow[b]{2}{*}{ R Square } & \multirow[b]{2}{*}{ R Square Adjusted } \\
\hline & & & & \\
\hline \multicolumn{3}{|c|}{ Foreign and Domestic Tourists } & 0.630 & 0.625 \\
\hline \multicolumn{3}{|c|}{ Hotel Occupancy Rates } & 0.475 & 0.467 \\
\hline
\end{tabular}

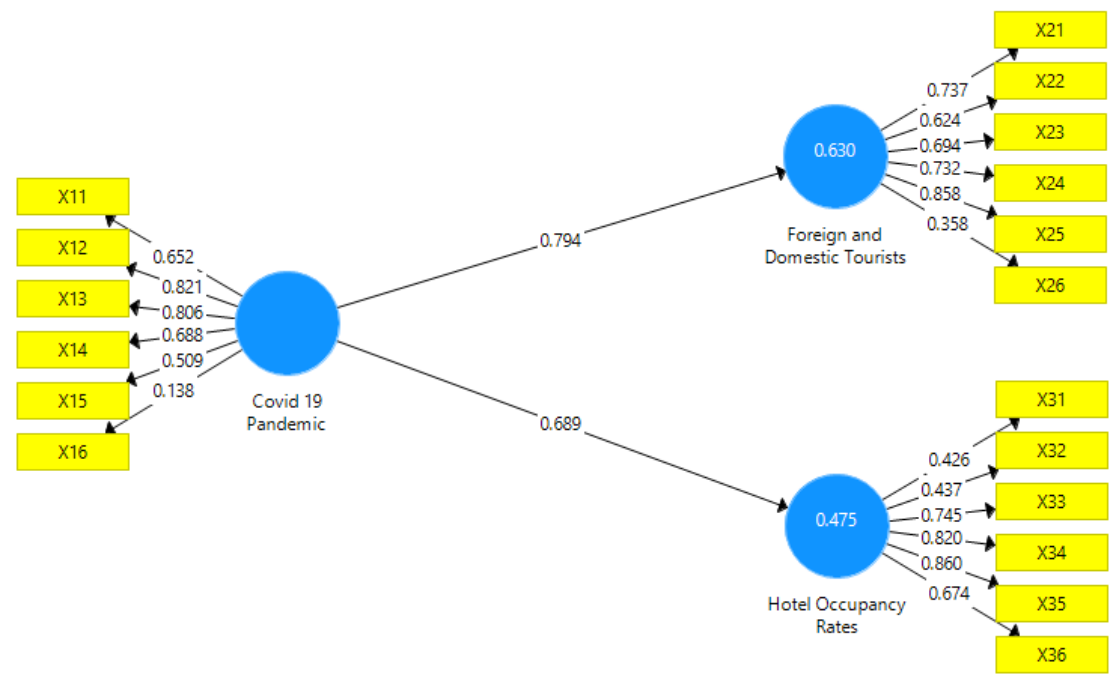

Gambar 7. R Square

Berdasarkan table 11 untuk menguji pengukuran model fit atau goodness of fit (GOFI) dapat digunakan indikator Standardized Root Mean Square Residual (SRMR), the Squared Euclidean distance (d_ULS), the Geodesic Distance (d_G), Chi Square dan Normed Fit Index (NFI). Standardized Root Mean Residual (SRMR) atau nilai rata-rata semua residual yang distandarisasi sebesar 0,139 dapat dikatakan dapat diterima apabila SRMR berkisar antara 0 1. D_ULS sebesar 3,294, D_U sebesar 1,189 dan Chi Square sebesar 390,155 serta Normed Fit Index (NFI) sebesar 0,485 dapat diartikan dapat diartika apabila nilai NFI berkisar antara 0 1. Seluruh indikator mempunai nilai kecocokan baik.

Tabel 11. Model Fit

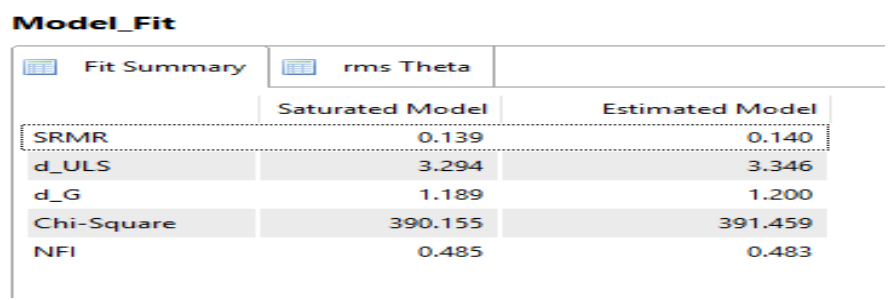

Sumber: Hasil Pengolahan Data (2020) 
Submitted: 11 Agustus 2020; Revised: 26 Agustus 2020; Accepted: 22 September 2020; Published: 30 September 2020

\section{Dampak Pandemik Covid-19 terhadap Kunjungan Turis Asing dan Domestik di Indonesia}

Hipotesis pertama bahwa thitung $(16,673) \geq t$ tabel $(1,990)$ dan nilai $P$ hitung $(0,001) \leq$ $P$ tabel $(0,05)$, dapat diartikan ada pengaruh pandemik pandemik covid-19 terhadap kunjungan turis asing dan domestik di Indonesia. Semakin banyak turis asing yang menunda kunjungannya ke Indonesia disebabkan karena semakin lama pandemic covid 19 berlangsung sejak Maret hingga Juni 2020. Begitu pula hal yang sama, semakin banyak turis domestik yang menunda kunjungannya ke beberapa kota dan provinsi di Indonesia disebabkan karena semakin lama pandemic covid 19 berlangsung sejak Maret hingga Juni 2020.

Indikator pandemic covid-19 yang paling dominan adalah semakin meningkatnya penduduk Indonesia yang terinfeksi covid 19 dikhawatirkan dapat menyebarkan covid 19 kepada turis asing dan domestik. Indikator pandemic covid 19 lainnya adalah kualitas alat pelindung diri belum sesuai standar Kementerian Kesehatan dan World Health Organization, belum lengkapnya fasilitas rumah sakit di beberapa kota di Indonesia, keterbatasan jumlah dokter yang menangani pandemic covid 19 dan vaksin anti covid-19 belum diketemukan. Sedangkan indikator turis asing yang paling dominan adalah peraturan Menteri Hukum dan Hak Asasi Manusia Republik Indonesia tentang pelarangan sementara turis asing masuk ke wilayah Negara Kesatuan Republik Indonesia dibandingkan indikator lainnya seperti moda transportasi udara dan laut, kualitas dan kuantitas destinasi pariwisata serta menghadiri undangan bisnis, seminar dan konferensi internasional. Indikator turis domestik yang paling dominan adalah penutupan sementara tempat-tempat wisata dibandingkan dengan indikator turis domestik lainnya seperti rekreasi, menghadiri undangan keluarga, bisnis, seminar dan konferensi.

Penelitian ini mendukung penelitian sebelumnya yang dilakukan oleh (Kumar, 2020) dengan judul "Indian Tourism Industry and Covid-19: Present Scenario mengatakan bahwa biro dan agen perjalanan serta operator sedang menghadapi krisis keuangan dalam waktu dekat ini (Pandemik Covid-19) karena frekuensi turis asing dan domestic untuk mengunjungi India akan terus mengalami penurunan. Semua segmen pariwisata inbound, outbound, domestik, MICE akan terpengaruh. Cara pemesanan hotel dibatalkan, dengan cara yang sama paket yang dijual oleh agen perjalanan dan operator tur untuk segmen inbound, outbound, domestik juga dibatalkan. Segmen MICE adalah salah satu segmen penting sesuai dengan perolehan pendapatan untuk biro perjalanan tetapi karena krisis saat ini semua jenis acara, pertemuan, konferensi telah dibatalkan atau ditunda.

Penelitian ini juga mendukung data dari (Ministry of Tourism and Economy Creative of the Republic of Indonesia, 2020) dan (Biro Pusat Statistik, 2020a) yang mengatakan bahwa pandemic covid-19 berpengaruh terhadap penurunan sebesar $59,96 \%$ turis asing yang berkunjung ke Indonesia pada bulan Januari hingga Juni 2020 berjumlah 3.089 .659 orang dibandingkan pada bulan Januari hingga Juni 2020 berjumlah 7.715 .512 orang. Turis asing yang berkunjung ke Indonesia pada bulan Januari hingga Juni berasal dari negara Malaysia, Timor Leste, Singapore, Australia, Chinese, India dan Japanese. Begitu pula pandemic covid19 juga berpengaruh pada penurunan sebesar $69,09 \%$ turis domestik pada bulan Januari 
hingga Juni 2020 berjumlah 85.000 .000 orang dibandingkan pada bulan Januari hingga Juni 2020 berjumlah $275,000,000$ orang.

\section{Dampak Pandemik Covid-19 terhadap Tingkat Hunian Kamar Hotel di Indonesia}

Hipotesis kedua bahwa t hitung $(9,738) \geq t$ tabel $(1,990)$ dan nilai $P$ hitung $(0,001) \leq P$ tabel $(0,05)$, dapat diartikan ada pengaruh pandemik pandemik covid-19 terhadap tingkat hunian hotel di Indonesia. Semakin lama pandemic covid 19 berlangsung sejak Maret hingga Juni 2020, maka aka semakin menurun tingkat hunian hotel bintang di Indonesia.

Indikator pandemic covid-19 yang paling dominan adalah semakin meningkatnya penduduk Indonesia yang terinfeksi covid 19 dikhawatirkan dapat menyebarkan covid 19 kepada turis asing dan domestik. Indikator pandemic covid 19 lainnya adalah kualitas alat pelindung diri belum sesuai standar Kementerian Kesehatan dan World Health Organization, belum lengkapnya fasilitas rumah sakit di beberapa kota di Indonesia, keterbatasan jumlah dokter yang menangani pandemic covid 19 dan vaksin anti covid-19 belum diketemukan.

Sedangkan indikator tingkat hunian hotel yang paling dominan adalah peraturan Menteri Hukum dan Hak Asasi Manusia Republik Indonesia tentang pembatasan kegiatan di tempat atau fasilitas umum dan pembatasan moda transportasi apabila dibandingkan indikator lainnya seperti harga kamar hotel, kualitas pelayanan hotel dan fasilitas hotel.

Penelitian ini mendukung penelitian sebelumnya yang dilakukan oleh (Xu \& Zhang, 2020) dengan judul "Covid-19 and Chinese Hotel Sector" yang mengatakan bahwa 498 responden yang terdiri dari pemilik dan operator hotel menyebutkan pandemic covid-19 berdampak pada penurunan tingkat hunian hotel mengalami sebesar $89 \%$ menjadi hanya $10 \%$ pada bulan januari dan Februari 2020 dengan perincian 40\% hotel tutup, 40\% sebagian ditutup dan dibuka serta $20 \%$ tetap buka. Penelitian ini juga mendukung penelitian sebelumnya yang dilakukan oleh (Sobieralski, 2020) dengan judul "Covid-19 and airline employment: Insights from historical uncertainty shocks to the industry" yang mengatakan bahwa kehilangan pekerjaan maskapai penerbangan diperkirakan $7 \%$ hingga $13 \%$ selama covid- 19 .

Penelitian ini juga mendukung penelitian sebelumnya yang dilakukan (Kementerian Pariwsiata dan Ekonomi Kreatif Republik Indonesia, 2020) bahwa tingkat hunian hotel bintang di 34 Provinsi di Indonesia pada bulan Januari hingga Juli 2020 sebesar 32,41\% atau mengalami penurunan sebesar $60,10 \%$ apabila dibandingkan tingkat hunian hotel bintang di 34 Provinsi di Indonesia pada bulan Januari hingga Juli 2019 sebesar 51,89.

\section{Kesimpulan}

Ada pengaruh pandemik pandemik covid-19 terhadap kunjungan turis asing dan domestik di Indonesia. Semakin banyak turis asing yang menunda kunjungannya ke Indonesia disebabkan karena semakin lama pandemic covid 19 berlangsung sejak Maret hingga Juni 2020. Begitu pula hal yang sama, semakin banyak turis domestik yang menunda kunjungannya ke beberapa kota dan provinsi di Indonesia disebabkan karena semakin lama pandemic covid Copyright @ 2020 Jurnal JKI 20 (3): 291 - 308 (September 2020) 
Submitted: 11 Agustus 2020; Revised: 26 Agustus 2020; Accepted: 22 September 2020; Published: 30 September 2020

19 berlangsung sejak Maret hingga Juni 2020. Indikator pandemic covid-19 yang paling dominan adalah semakin meningkatnya penduduk Indonesia yang terinfeksi covid 19 dikhawatirkan dapat menyebarkan covid 19 kepada turis asing dan domestik. Indikator pandemic covid 19 lainnya adalah kualitas alat pelindung diri belum sesuai standar Kementerian Kesehatan dan World Health Organization, belum lengkapnya fasilitas rumah sakit di beberapa kota di Indonesia, keterbatasan jumlah dokter yang menangani pandemic covid 19 dan vaksin anti covid-19 belum diketemukan. Sedangkan indikator turis asing yang paling dominan adalah peraturan Menteri Hukum dan Hak Asasi Manusia Republik Indonesia tentang pelarangan sementara turis asing masuk ke wilayah Negara Kesatuan Republik Indonesia dibandingkan indikator lainnya seperti moda transportasi udara dan laut, kualitas dan kuantitas destinasi pariwisata serta menghadiri undangan bisnis, seminar dan konferensi internasional. Indikator turis domestik yang paling dominan adalah penutupan sementara tempat-tempat wisata dibandingkan dengan indikator turis domestik lainnya seperti rekreasi, menghadiri undangan keluarga, bisnis, seminar dan konferensi.

Daftar Pustaka

Biro Pusat Statistik. (2018a). Domestic Tourists Based on Provincial Residences. Biro Pusat Statsitik.

https://www.bps.go.id/publication/download.html?nrbvfeve=NTI0OWMyYjYONWUyMTI5M WI1MWRmYzFh\&xzmn=aHR0cHM6Ly93d3cuYnBzLmdvLmlkL3B1YmxpY2F0aW9uLzIw MTkvMDcvMDIvNTI0OWMyYjYONWUyMTI5MWI1MWRmYzFhL3NOYXRpc3Rpay13aXNh dGF3YW4tbnVzYW50YXJhLTIwMTguaHRtbA\%3D\%3D\&twoadfn

Biro Pusat Statistik. (2018b). Statistik Hotel dan Tingkat Penghunian Kamar Hotel DKI Jakarta 2018 (D. Kundalini \& A. Latif (eds.); 1st ed.). Biro Pusat Statistik.

Biro Pusat Statistik. (2018c). Statistik Wisatawan Nusantara. Biro Pusat Statsitik. https://www.bps.go.id/publication/download.html?nrbvfeve=NTI0OWMyYjYONWUyMTI5M WI1MWRmYzFh\&xzmn=aHR0cHM6Ly93d3cuYnBzLmdvLmlkL3B1YmxpY2F0aW9uLzIw MTkvMDcvMDIvNTI0OWMyYjYONWUyMTI5MWI1MWRmYzFhL3NOYXRpc3Rpay13aXNh dGF3YW4tbnVzYW50YXJhLTIwMTguaHRtbA\%3D\%3D\&twoadfn

Biro Pusat Statistik. (2020a). Foreign Tourists Based on Countries Residences in 2019 and 2020. Biro Pusat Statistik. https://www.bps.go.id/pressrelease/2020/08/03/1717/jumlahkunjungan-wisman-ke-indonesia-juni-2020-mencapai-160-28-ribu-kunjungan-.html

Biro Pusat Statistik. (2020b). Konsep dan Definisi Statistik Kunjungan Wisatawan Mancanegara. Biro Pusat Statsitik. https://www.bps.go.id/subject/16/pariwisata.html

CNN. (2020, April 17). Pendapatan Sektor Penerbangan Melayang Rp 207 M karena Corona. CNN, $\quad 1 . \quad$ https://www.cnnindonesia.com/ekonomi/20200417150745-92494588/pendapatan-sektor-penerbangan-melayang-rp207-m-karena-corona

Gunay, F., Bayraktaroglu, E., \& Ozul, K. (2020). Assessing the Short-term Impacts of COVID-19 Pandemic on Foreign Visitor's Demand for Turkey: A Scenario Analysis. Jurnal of 
Ekonomi, 04(1), 80-85. https://dergipark.org.tr/tr/pub/ekonomi/issue/53627/726036

Hoque, A., Shikha, F. A., Hasanat, M. W., Arif, I., \& Hamid, A. B. A. (2020). The Effect of Coronavirus (COVID-19) in the Tourism Industry in China. Asian Journal of Multidiciplinary Studies, 3(1), 52-58. https://asianjournal.org/online/index.php/ajms/article/view/213 International Labour Organization. (2020). Covid -19 and the World of Work: Impact and Policy Responses. Website. https://news.trust.org/item/20200318134210-5pmjc

Kementerian Pariwsiata dan Ekonomi Kreatif Republik Indonesia. (2020). Statistik Tingkat Penghunian Kamar Hotel Bintang Tahun 2020. Kementerian Pariwsiata Dan Ekonomi Kreatif Republik Indonesia. https://www.kemenparekraf.go.id/post/statistik-tingkatpenghunian-kamar-hotel-bintang-tahun-2020

Kumar, V. (2020). Indian Tourism Industry and COVID-19: Present Scenario. Journal of Tourism \& Hospitality Education, 10, 1-7. https://doi.org/DOI: https://doi.org/10.3126/jthe.v10i0.28768

Kusubandio, W. (2020). Rancangan Teknokratis Rencana Strategis 2020-2024. Ministry of Tourism and Creative Economy of the Republic of Indonesia. http://eperformance.kemenpar.go.id/dokumen/52Draft Naskah Tekonkratik Renstra 2020 2024.pdf

Laoly, Y. H. (2020). Regulation of the Minister of Law and Human Rights of the Republic of Indonesia Number 11 of 2020. Ministry of Law and Human Rights of the Republic of Indonesia. $\quad$ https://www.imigrasi.go.id/uploads/07-10-24PERMENKUMHAM_NOMOR_11_TAHUN_2020_TENTANG_PELARANGAN_SEMENTA RA_ORANG_ASING_MASUK_WILAYAH_NEGARA_REPUBLIK_INDONESIA.pdf

Makki, S. (2020, June 2). Garuda Indonesia Rumahkan 800 Karyawan Kontrak. CNN, 1. https://www.cnnindonesia.com/ekonomi/20200602140628-92-508991/garuda-indonesiarumahkan-800-karyawan-kontrak

Minister of Health of the Republic of Indonesia. (2020). Dashboard Kasus COVID-19 di Indonesia. Website.

Ministry of Tourism and Economy Creative of the Republic of Indonesia. (2020). Foreign Tourists Data in 2020. Ministry of Tourism and Economy Creative of the Republic of Indonesia. https://www.kemenparekraf.go.id/post/data-kunjungan-wisatawanmancanegara-bulanan-tahun-2020

President of the Republic of Indonesia. (2020). Government Regulation of the Republic of Indonesia Number 21 of 2020 concerning Large-Scale Social Restrictions in the Context of Accelerating the Handling of Corona Virus Disease 2019. Website. https://jdih.setkab.go.id/PUUdoc/176085/PP_Nomor_21_Tahun_2020.pdf

Ramli, R. R., \& Djumena, E. (2020). Penerbangan Rute China Ditutup, Menhub Usul Pesawat $\begin{array}{lllll}\text { Digunakan ke Negara } & \text { Ini. } & \text { Kompas, } & 1 .\end{array}$ https://money.kompas.com/read/2020/02/04/063900326/penerbangan-rute-china-ditutupmenhub-usul-pesawat-digunakan-ke-negara-ini?page=all 
Ramli, R. R., \& Sukmana, Y. (2020, July 2). Imbas Covid-19, Lion Air Pangkas 2.600 Karyawan. Kompas, 1. https://money.kompas.com/read/2020/07/02/170502026/imbas-covid-19-lionair-pangkas-2600-karyawan?page=all

Saleem, A. S. M. R. Al, \& Al-Juboori, N. F. M. (2013). Factors Affecting Hotels Occupancy Rate (An Empirical Study on Some Hotels in Amman). Interdiciplinary Journal of Contemporary Research in Business, 5(6), 142-159. https://doi.org/10.13140/RG.2.2.35688.16649

Sobieralski, J. B. (2020). Covid-19 and airline employment: Insights from historical uncertainty shocks to the industry. Transportation Research Interdisciplinary Perspectives, 100-123. https://doi.org/DOI:https://doi.org/10.1016/j.trip.2020.100123

Stanislav Ivanov. (2014). Hotel Revenue Management from Theory to Practice (S. F. Illum \& M. $\begin{array}{llllll}\text { K. Dokuz } & \text { (eds.); } & \text { 1st } & \text { ed.). }\end{array}$ https://www.researchgate.net/publication/262918029_Hotel_Revenue_Management_From _Theory_to_Practice

Task Force to Accelerate the Handling of Covid-19. (2020). Covid-19 Pandemic Cases in Indonesia. Task Force to Accelerate the Handling of Covid 19. https://covid19.go.id/petasebaran

Terawan Agus Putranto. (2020). Regulation of the Health Minister of the Republic of Indonesia $\begin{array}{lllll}\text { Number } & 9 & \text { of } & 2020 . & \text { Kementerian Resehatan RI. }\end{array}$ http://hukor.kemkes.go.id/uploads/produk_hukum/PMK_No_9_Th_2020_ttg_Pedoman_P embatasan_Sosial_Berskala_Besar_Dalam_Penanganan_COVID-19.pdf

Wareza, M. (2020, July 1). Baru Saja Untung, Garuda Merugi Lagi di Q1-2020 karena Covid. CNBC Indonesia, 1. https://www.cnbcindonesia.com/market/20200701182341-17169535/baru-saja-untung-garuda-merugi-lagi-di-q1-2020-karena-covid

Wen, J., \& Jiang, Y. (2020). Effects of COVID-19 on hotel marketing and management: A perspective article. International Journal of Comtemporary of Hospitality Management, 87, 1. https://doi.org/DOI: 10.1108/IJCHM-03-2020-0237

WHO. (2020). Question and Answer for Public Concerning Covid-19. World Health Organization. https://www.who.int/indonesia/news/novel-coronavirus/qa-for-public

Xu, C., \& Zhang, C. (2020). COVID-19 and the Chinese Hotel Sector. HVS CHina. https://www.hvs.com/article/8723-COVID-19-and-the-Chinese-Hotel-Sector 